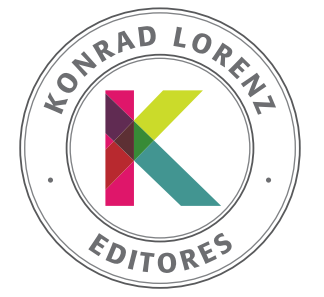

SUMA PSICOLÓGICA

http://editorial.konradlorenz.edu.co/suma-psicologica.html

\title{
Development and validation of the Inventory of Emotional and Reasoned Purchases Decision-Making Styles (PDMI)
}

\author{
Francisco Leonardo Soler Anguiano ${ }^{a}$, José Marcos Bustos Aguayoa, \\ Jorge Palacios ${ }^{b}$, Marcel Zeelenbergc,d y Rolando Díaz Lovinge
}

\author{
a Universidad Nacional Autónoma de México, Facultad de Estudios Superiores Zaragoza, México \\ ${ }^{b}$ Universidad del Valle de México, Campus Querétaro, México \\ c Tilburg University, Tilburg Institute for Behavioral Economics Research, Department of Social Psychology, Netherlands \\ ${ }^{d}$ Vrije Universiteit Amsterdam, Department of Marketing, Netherlands \\ e Universidad Nacional Autónoma de México, Facultad de Psicología, México
}

Received 6 May 2019; Accepted 13 August 2019

\author{
KEYWORDS \\ Consumer behavior, \\ Psychometrics, \\ Economic Psychology, \\ Expenditure, \\ Mexicans
}

\begin{abstract}
Consumer decision-making is part of the purchase process. Therefore, as a relevant element for the evaluation of the purchase process, it is essential to have valid, reliable and culturally relevant measurements. For that reason, in this study the development and validation of the Purchases Decision-Making Inventory (PDMI) are presented. The general sample consisted of 518 Mexican participants, which were randomly divided into two groups, 300 for exploratory analysis, and 218 for confirmatory analysis. The results show that PDMI evaluated from its general components of emotional and reasoned decisions in purchases, present high internal consistency. The confirmatory factor analysis shows a good fit to dimensions extracted from the exploratory analyses. In terms of convergent, divergent, and discriminant validity, relations according to the nomological network were found, and the factors showed independency. Finally, from the confirmed structures of the inventory, spending per week was modelled, finding that emotional decisions turned out to be a positive significant predictor. PDMI is an evaluation tool with cultural relevance and appropriate psychometric indexes that can be used to integrate into consumer behavior models.
\end{abstract}

(c) 2019 Fundación Universitaria Konrad Lorenz. This is an open access article under the CC BY-NCND license (http://creativecommons.org/licenses/bync-nd/4.0/).

\section{Desarrollo y validación del Inventario de Estilos de Toma de Decisiones de Compras Emocionales y Razonadas (ITDC)}

Resumen La toma de decisiones del consumidor es parte del proceso de compra. Por tanto, al ser un elemento relevante para la evaluación del proceso de compra, es esencial contar con mediciones válidas, confiables y culturalmente relevantes. Por esta razón, en este artículo se presenta el desarrollo y validación del inventario de toma de decisiones de compras (ITDC). La muestra general estuvo conformada por 518 participantes mexicanos, la cual se dividió

\section{PALABRAS CLAVE \\ Comportamiento \\ del Consumidor, \\ Psicometría, \\ Psicología Económica, \\ Gasto, Mexicanos}

* Autor para correspondencia.
Correo electrónico: psicleonardosoler@gmail.com

http://dx.doi.org/10.14349/sumapsi.2019.v26.n2.3

0120-0534/@ 2019 Fundación Universitaria Konrad Lorenz. Este es un artículo Open Access bajo la licencia CC BY-NC-ND (http://creativecommons.org/licenses/by-nc-nd/4.0/). 
aleatoriamente en dos, 300 para análisis exploratorios y 218 para análisis confirmatorios. Los resultados muestran que el ITDC, evaluado a partir de sus componentes generales de decisiones emocionales y razonadas en las compras, presenta altos índices de consistencia interna. $\mathrm{El}$ análisis factorial confirmatorio muestra buen ajuste a las dimensiones extraídas en los análisis exploratorios. En términos de validez convergente, divergente y discriminante, se encontraron relaciones según la red nomológica, y los factores mostraron independencia. Por último, a partir de las estructuras confirmadas del inventario, se modeló el gasto por semana. Encontrando que las decisiones emocionales resultan ser un predictor significativo positivo. ITDC es una herramienta de evaluación con relevancia cultural e índices psicométricos apropiados, que se pueden utilizar para integrar en modelos de comportamiento del consumidor.

(c) 2019 Fundación Universitaria Konrad Lorenz. Este es un artículo Open Access bajo la licencia CC BY-NC-ND (http://creativecommons.org/licenses/bync-nd/4.0/).

Consumers are constantly exposed to situations where they are required make a decision. For instance, they have to decide whether or not to buy a product, or to purchase one brand rather than another. In fact, consumers identify that the product/service feature, such as utility and duration, is the most important consideration at the time of making a purchase, followed by price. This is according to $70 \%$ of the 6,400 consumers in 23 countries around the world (Simon-Kucher \& Partners, 2019). It has been shown to be part of the psychological meaning of reasoned consumption (Soler, Palacios, Bustos, \& Díaz-Loving, 2018). At the same time, $80 \%$ of consumers in the CNBC \& SurveyMonkey (2019) survey, report having bought something on impulse. This illustrates that there are many ways in which consumers make decisions, both by paying attention to the attributes and price of a product, or on impulse.

These different ways of making decisions are described by what is typically known as consumer decision making styles. Sproles and Kendall (1986, p. 268), pioneers in this field, define a consumer decision making style as "a mental orientation characterizing a consumer's approach to making choices. It has cognitive and affective characteristics (for example, quality consciousness and fashion consciousness). In essence, it is a basic consumer personality, analogous to the concept of personality in psychology."

Consumer decision making style is an important psychological construct, because it has been shown to explain a large variety of behaviors in the consumer and economics fields. For instance, consumer decision making style predicts customer loyalty (McDonald, 1993), mall shopping (Wesley, LeHew \& Woodside, 2006) customer satisfaction and purchase intention (Alavi, Razaei, Valaei, \& Wan, 2015), and online consumer behaviour (Sam \& Chatwin, 2015).

The main challenge in the field of consumer decision making styles is creating a valid and reliable way of assessing them. That is, constructing a set of questions that capture the different styles or "consumer personality" that people can adopt when purchasing products. Sproles and Kendall (1986) generated such a questionnaire. The dimensions identified by them include: (1) perfectionism and high-quality consciousness, (2) brand consciousness, (3) novelty and fashion, (4) hedonic and recreational buying, (5) price as a value, (6) impulsiveness, (7) confusion over information, (8) loyalty, and (9) habituation.

Sproles and Kendall (1986) thus proposed an original way of looking at consumer decision making, by implementing the idea of a somewhat stable consumer personality in the form of various consumer decision making styles.
Unfortunately, the measurement of these different styles turned out not to be very reliable. The internal consistency of the dimensions ranged from 0.48 to 0.76 , showing low reliability. Follow-up research confirmed that this questionnaire does not have the appropriate psychometric properties (e.g., Shim, 1996). In addition to the low reliabilities, the factor structure does not replicate well, and there is substantial cultural variability (see Chaudhary \& Dey, 2016; Lysonski, Durvasula \& Zotos, 1996).

Some of these limitations may stem from the fact that the questionnaire was uniquely based on literature and not on empirical research. As a result, the measurement may have missed relevant dimensions that were not yet identified in the literature. However, the measure includes an affective item, exploring the hedonic and pleasure dimension, neglecting negative emotions, that have been identified as influencing consumer decision-making (Chuang \& Lin, 2007).

The goal of the present research is to build upon the original idea of Sproles and Kendall (1986) and to develop a valid and reliable way of measuring consumer decision making styles in order to assess these styles in Mexico. If we succeed in doing so, we would like to examine whether this scale can also be used in other cultures.

In order to create such a scale, we will redact a large number of items that potentially assess the different styles that came from a preliminary study (see Soler et al., 2018). In that Study, 72 Mexican people (36 men and 36 women with an age range of 18 to 54 years $M=32.56, S D=11.47$ ) participated. Consumption decision-making styles were assessed via the technique of modified natural semantic networks (Reyes, 1993). This technique proposes that a measurement should be developed with the use of a representative sample of behaviors, focus on universal and cultural relevant behavioral manifestations, and come from the explorations that people have about the meaning of the construct to measure. Highlighting the role that people have in the creation of measures, psychological meaning was extracted from the target population (cf., Reyes, 1993). Two stimuli words were used, "Impulsive consumption" and "Reasoned consumption”, in line with Sproles and Kendall's (1986) cognitive and affective decision styles, and with Kahneman's (2011) deliberate and slow versus intuitive, emotional and fast systems. These ideas about two dimensions of consumer decision making also find support in Bachkirov (2015) for management decisions, and in Shiv and Fedorikhin (1999) in the consumer decisions area. 
The emotional and rational decision styles are expected to be made up from different components. In the emotional purchase decision style, pleasure and excitement are expected to be components in this dimension, which at the same time are related to impulsive shopping (Babin \& Darden, 1996). In the field of negative emotions, sadness, has been associated with consumer transactions and specifically monetary spending (Cryder, Lerner, Gross \& Dahl, 2008; Garg, Williams \& Lerner, 2018; Lerner, Small \& Loewenstein, 2004). In the rational purchase decision style, we expect to find product quality, economy, and value or performance, which according to Kotler and Armstrong (1994) are involved in the advertisement message that impacts consumers and influences a purchase. And also negative dimensions like indebtedness, which has been identify related to personality traits like consumer locus of control (Mansilla, Denegri \& Álvarez, 2016).

In a new study, we will obtain factor analyse to reveal the underlying structure. In order to assess convergent and divergent validity we will relate the obtained structure to emotions and affective states of purchases scale (Palacios \& Viloria, 2017). We use the scale from Palacios and Viloría (2017) because it is an instrument that meets the criteria of reliability and validity, as well as cultural sensitivity having been carried out in Mexican sociocultural context. In order to examine discriminant validity, we will obtain the average variance extracted. To assess predictive validity, we will model spending per week with emotional and reasoned scales from the PDMI. We expect that emotional decision styles have a stronger influence on spending than reasoned decision styles. This expectation is based on Vida and Reardon (2008), who identified that affective and normative constructs are stronger determinants in domestic consumption than rational constructs.

\section{Method}

\section{Participants}

The sample was composed of 518 people selected from a non-probabilistic sampling of university students, their relatives, and acquaintances. The sample was randomly divided, leaving 300 people for the exploratory analysis sample size recommended by Comrey and Lee (1992), and 218 for confirmatory analysis - sample size recommended by Hoelter (1983) in CFA (see Table 1).

\section{Instruments}

The preliminary study (Soler et al., 2018) resulted in 107 items, identifying two scales: emotional decision styles (61 items) and reasoned decision styles (46 items). For the inventory, a frequency scale format of five points was used $(1=$ never $-5=$ always $)$. All the items were reviewed and evaluated by three expert judges ( 2 psychometricians, and 1 economic psychologist). Once the items battery was formed, a pilot with 20 people was carried out to identify some additional adjustments in the items.

The Emotions and affective states of purchases scale by Palacios and Viloria (2017) was developed in order to evaluate emotions when shopping. It consists of 48 emotions, in which people are asked to evaluate the intensity of each affective state felt during the purchases made last year
( 1 = Nothing intense $-10=$ Very intense). This scale is composed of two factors: positive emotions (e.g., satisfaction, blissful, happy), and negative emotions (e.g., irritable, fearful, sad).

Additionally, a sociodemographic data section was included where they were asked about their age, sex, place of residence, and spending per week; this last asked in the following way "How much money do you spend on average per week?"

Table 1 Description of total sample and subsamples used in the EFA and CFA.

\begin{tabular}{|c|c|c|c|c|c|c|}
\hline \multirow[t]{3}{*}{ Variables } & \multicolumn{2}{|c|}{ Total } & \multicolumn{2}{|c|}{ EFA } & \multicolumn{2}{|c|}{ CFA } \\
\hline & \multicolumn{2}{|c|}{$N=518$} & \multicolumn{2}{|c|}{$N=300$} & \multicolumn{2}{|c|}{$N=218$} \\
\hline & \multicolumn{2}{|c|}{$\%$} & \multicolumn{2}{|c|}{$\%$} & \multicolumn{2}{|c|}{$\%$} \\
\hline \multicolumn{7}{|l|}{ Sex } \\
\hline Women & \multicolumn{2}{|c|}{57.3} & \multicolumn{2}{|c|}{60.3} & \multicolumn{2}{|c|}{53.2} \\
\hline Men & \multicolumn{2}{|c|}{42.7} & \multicolumn{2}{|c|}{39.7} & \multicolumn{2}{|c|}{46.8} \\
\hline \multicolumn{7}{|l|}{$\begin{array}{l}\text { Place of } \\
\text { residence }\end{array}$} \\
\hline $\begin{array}{r}\text { Ciudad de } \\
\text { México }\end{array}$ & \multicolumn{2}{|c|}{56.9} & \multicolumn{2}{|c|}{53.5} & \multicolumn{2}{|c|}{61.5} \\
\hline Querétaro & \multicolumn{2}{|c|}{27} & \multicolumn{2}{|c|}{28.8} & \multicolumn{2}{|c|}{24.8} \\
\hline $\begin{array}{r}\text { Estado de } \\
\text { México }\end{array}$ & \multicolumn{2}{|c|}{10.4} & \multicolumn{2}{|c|}{11.7} & \multicolumn{2}{|c|}{8.7} \\
\hline Guanajuato & \multicolumn{2}{|c|}{.8} & \multicolumn{2}{|c|}{.7} & \multicolumn{2}{|c|}{.9} \\
\hline \multirow[t]{2}{*}{ Guerrero } & \multicolumn{2}{|c|}{4.8} & \multicolumn{2}{|c|}{5.4} & \multicolumn{2}{|c|}{4.1} \\
\hline & $M$ & SD & $M$ & SD & $M$ & SD \\
\hline Age & 29.87 & 10.91 & 29.71 & 10.83 & 30.08 & 11.04 \\
\hline $\begin{array}{l}\text { Spending } \\
\text { per week } \\
\text { (Mexican } \\
\text { pesos) }\end{array}$ & 1132.64 & 890.52 & 1175.82 & 868.61 & 1232.92 & 1216.19 \\
\hline
\end{tabular}

Notes

$\mathrm{EFA}=$ Exploratory Factor Analysis

CFA $=$ Confirmatory Factor Analysis

\section{Procedure}

The instrument was applied in public places, homes, and universities. The participants were asked for their voluntary collaboration. All participants were assured that the information was anonymous and that the data they provided was confidential. Each participant provided verbal consent. The research protocol was established according to the General Health Regulations specifically the section regarding research on human beings. The study project collaborates with the research project "Neuroeconomic factors of financial and consumption behavior" which is evaluated by the Bioethics Committee and registered with the Research Committee of the Universidad del Valle de Mexico, Querétaro Campus, with the registration number CSUVMI2017-002.

\section{Data analysis}

The data was analysed in IBM SPSS Statistics version 25 (IBM Corp., 2017) for the Exploratory Factor Analysis (EFA), 
and AMOS version 24 was used (Arbuckle, 2016) for the Confirmatory Factor Analysis (CFA).

The data was analysed from four stages of the study: First, the descriptive statistics of each item, and Student $t$-tests for independent samples. In the second stage, the EFA was carried out with a first subsample $(N=300)$, and internal consistency index (Cronbach's alpha). Later, the correlations between factors were analysed. In the third stage, CFA was carried out with the second subsample $(N=218)$, from Structural equation modelling (SEM), and the analysis of covariance between latent variables. In the fourth phase, correlation analysis and average variance estimated (AVE) were carried out, in addition to the structural modelling for the analysis of covariance between the scales and the prediction of spending per week.

\section{Results}

The Purchase Decision-Making Inventory (PDMI) was composed of two scales, the Scale of Emotional Decisions in Purchases (PDMI-Emotional), and the Scale of Decisions in Reasoned Purchases (PDMI-Reasoned). Therefore, the Exploratory Factor Analysis (EFA) and the Confirmatory Factor Analysis (CFA) are presented separately for each scale.

\section{Phase 1. - Descriptive statistics and items discrim- ination}

Skewness and kurtosis indicators were obtained for each item. With respect to skewness, two items of the PDMI-Emotional presented indexes greater than 2, which were kept in sight, in case they fell in some other indicator that requires removal from later analyses. While all those that correspond to the PDMI-Reasoned presented indicators between -.87 to 1.90 , all within the acceptable range. With respect to kurtosis, ten PDMI-Emotional items presented indexes greater than 2 . Two were those that obtained equally high scores in skewness. Therefore, those two items were eliminated for further analyses. The kurtosis indicators from the PDMI-Reasoned were between -.975 and .551; all within the acceptable range.

Subsequently, a total score of each scale and quartiles were obtained to create a new variable for the PDMI-Emotional and another for the PDMI-Reasoned, dividing the high and low scores, from the quartiles 1 and 3 . The discrimination of the items was analysed from Student $t$-tests for independent samples to each item by scale. Under this criterion, all the items showed statistically significant differences at $p<.001$ of the PDMI-Emotional. On the other hand, for the PDMI-Reasoned, it was identified that one item did not show statistically significant differences ( $t(217)=0.505, p=.618)$, due to this, the item was not included for future analyses.

\section{Phase 2. - Exploratory Factor Analysis (EFA)}

In order to obtain the construct validity of each scale, an EFA was carried out. In both cases, a reduction of dimensions was made from the maximum likelihood extraction method with orthogonal varimax rotation without forcing a certain number of factors. With this procedure, items that had factor loads less than .40 , or that loaded in two or more factors with differences of .20 or less in their factor load were eliminated - 31 items from PDMI-Emotional (e.g., I make better choices about what to buy when I'm happy; I've regretted buying some things), and 26 items from PDMI-Reasoned (e.g., I make a list before going shopping; I compare products before buying things).

\section{Scale of Emotional Decisions in Purchases (PDMI-Emotional)}

A composition of five factors with eigenvalues greater than 1 was obtained, explaining $48.75 \%$ of the total variance (see Table 2). The factorial solution converged in six iterations and an adequate KMO coefficient was presented with a value of .899; Bartlett $=4013.56, p<.001$. Factor loads greater than .454 and communalities greater than .341 were presented. Based on Pearson correlations, the association between factors was analysed, ranging from low to medium coefficient. Cronbach's alpha index shows a good internal consistency, for the general scale and for each factor.

The factorial analysis showed components that have been conceptualized as follows:

Impulsivity: Emotional decision style that involves buying without thinking about the economy, and buying at the time the product is desired.

Indebtedness: Emotional decision style that involves generating debts, spending money you don't have and borrowing money, all this to satisfy whims.

Frustration: Emotional decision style involving the feeling of anguish, frustration and feeling nervous when choosing between different products.

Hedonism: Emotional decision style that involves shopping for pleasure, happiness and enjoyment.

\section{Scale of Reasoned Decisions in Purchases (PDMI-Reasoned)}

A composition of three factors with eigenvalues greater than 1 was obtained, explaining $53.72 \%$ of the total variance (see Table 3 ). The factorial solution converged in six iterations, and an adequate KMO coefficient with a value of .908 was presented; Bartlett $=3321.42, p<.001$. Factorial loads greater than .448 and communalities greater than .320 were obtained. Based on Pearson correlations, the association between factors was analysed. Cronbach's alpha indices show a good internal consistency, for the general scale and each factor.

The factorial analysis showed components that have been conceptualized as follows:

Savings: Decision style that involves purchasing things in a conscious way, aimed at analysing each expense for the benefit of one's personal economy.

Reasoning: Reasoned decision style that involves processing, being analytical, and calmly and consciously deciding each purchase.

Information search: Reasoned decision style that involves consulting, being critical, and finding out about the products before making the purchase.

\section{Phase 3. - Confirmatory Factor Analysis (CFA)}

CFA of two scales created was carried out, in both cases, the goodness-of-fit estimation was used from the maximum likelihood method. 
Table 2 Sub-scales, factorial loads, psychometric index of internal consistency, inter-factor correlations and descriptive statistics of the PDMI-Emotional

\begin{tabular}{|c|c|c|c|c|c|}
\hline \multirow[b]{2}{*}{ Items } & \multicolumn{5}{|c|}{ Sub-scales } \\
\hline & Impulsivity & indebtedness & $\begin{array}{l}\text { Negative } \\
\text { emotions }\end{array}$ & Frustration & Hedonism \\
\hline C56. I bought compulsively. & .656 & .121 & .427 & .108 & .186 \\
\hline $\begin{array}{l}\text { C47. I buy things without thinking about the effect on my } \\
\text { economy. }\end{array}$ & .628 & .336 & .225 & .159 & .104 \\
\hline C55. When I do my shopping, I do not limit myself & .598 & .112 & .103 & .045 & .04 \\
\hline C50. I shop excessively. & .577 & .094 & .275 & .114 & .229 \\
\hline C57. When I do my shopping, I think that if I want it I have it. & .574 & .161 & .133 & .001 & .238 \\
\hline $\begin{array}{l}\text { C59. I avoid thinking about the consequences when making } \\
\text { my purchases. }\end{array}$ & .569 & .236 & .172 & .054 & -.013 \\
\hline C51. I decide fast without thinking, when I make purchases. & .551 & .162 & .089 & .031 & .05 \\
\hline C58. When I want something, I immediately buy it & .549 & .065 & .225 & .108 & .216 \\
\hline C60. I have bought using instinct. & .538 & .085 & .295 & .039 & .108 \\
\hline $\begin{array}{l}\text { C45. I have accumulated things that I have bought and do } \\
\text { not need. }\end{array}$ & .519 & .297 & .156 & .218 & -.001 \\
\hline $\begin{array}{l}\text { C46. I have bought things that I like at the moment but } \\
\text { not later. }\end{array}$ & .454 & .292 & .146 & .27 & .048 \\
\hline C34. I have generated debts when buying things. & .108 & .733 & .048 & -.094 & .228 \\
\hline $\begin{array}{l}\text { C30. I have spent money that I do not have when buying } \\
\text { things. }\end{array}$ & .166 & .686 & .21 & .001 & .043 \\
\hline C43. I have delayed making payments for services & .245 & .609 & .067 & .056 & -.123 \\
\hline C44. I have had a service suspended for not paying on time. & .182 & .598 & -.032 & .097 & -.101 \\
\hline C37. It's common for me to end up in debt to satisfy my whims. & .306 & .569 & .201 & -.009 & .135 \\
\hline C31. I have borrowed money to make a purchase. & .089 & .567 & .293 & .077 & .021 \\
\hline C11. When I'm depressed, I buy things. & .219 & .083 & .595 & .079 & .209 \\
\hline C19. When I'm angry, I spend more than I should. & .200 & .207 & .542 & .116 & -.003 \\
\hline C14. When I'm desperate I buy the first thing that I see. & .237 & .133 & .536 & .202 & .02 \\
\hline C20. I have bought things on a whim. & .283 & .075 & .527 & .154 & .081 \\
\hline C2. I have bought by anxiety. & .127 & .131 & .507 & .166 & .272 \\
\hline C15. My purchase is initiated by emotional needs. & .297 & .049 & .506 & .187 & .202 \\
\hline C9. I have bought things due to an outburst. & .204 & .253 & .471 & .184 & .243 \\
\hline $\begin{array}{l}\text { C5. It anguishes me to have to decide between several } \\
\text { products. }\end{array}$ & .07 & -.037 & .136 & .810 & .147 \\
\hline $\begin{array}{l}\text { C10. It frustrates me to have to decide between several } \\
\text { products. }\end{array}$ & .118 & .076 & .255 & .787 & .116 \\
\hline $\begin{array}{l}\text { C18. It makes me nervous to choose between different } \\
\text { products. }\end{array}$ & .121 & .057 & .265 & .707 & .038 \\
\hline C7. Buying is a pleasant activity for me. & .068 & -.001 & .243 & .105 & .783 \\
\hline C8. Shopping is one of the activities I enjoy most in life. & .165 & .055 & .198 & .032 & .774 \\
\hline C12. I feel happy when I buy things. & .267 & -.008 & .063 & .152 & .644 \\
\hline
\end{tabular}


Table 2 Sub-scales, factorial loads, psychometric index of internal consistency, inter-factor correlations and descriptive statistics of the PDMI-Emotional

\begin{tabular}{|c|c|c|c|c|c|c|}
\hline \multicolumn{7}{|c|}{ Total } \\
\hline Items number & 30 & 11 & 6 & 7 & 3 & 3 \\
\hline$\%$ variance explained & 48.75 & 14.26 & 9.98 & 9.79 & 7.36 & 7.34 \\
\hline Cronbach's alpha & .915 & .883 & .825 & .82 & .851 & .819 \\
\hline \multicolumn{7}{|l|}{ Correlations inter-factor } \\
\hline Impulsivity & & 1 & & & & \\
\hline Indebtedness & & $.492^{* *}$ & 1 & & & \\
\hline Negative emotions & & $.606^{* *}$ & $.309^{* *}$ & 1 & & \\
\hline Frustration & & $.320^{* *}$ & $.138^{*}$ & $.448^{* *}$ & 1 & \\
\hline Hedonism & & $.371^{* *}$ & $.140^{*}$ & $.427^{* *}$ & $.267^{* *}$ & 1 \\
\hline Mean (theoretical mean $=2.5$ ) & & 1.86 & 1.72 & 1.78 & 2.20 & 2.87 \\
\hline Standard deviation & & 0.68 & 0.66 & 0.68 & 1.00 & 1.02 \\
\hline
\end{tabular}

${ }^{*} p<.05$

${ }^{* *} p<.001$

Table 3. Sub-scales, factorial loads, psychometric index of internal consistency, inter-factor correlations and descriptive statistics of PDMI-Reasoned

\begin{tabular}{|c|c|c|c|}
\hline \multirow[b]{2}{*}{ Items } & \multicolumn{3}{|c|}{ Sub-scales } \\
\hline & Saving & Reasoning & $\begin{array}{c}\text { Search of } \\
\text { information }\end{array}$ \\
\hline C82. I take care every spend that I do. & .790 & .298 & .148 \\
\hline C83. I control every expense before buying. & .777 & .321 & .175 \\
\hline C84. When purchasing things, I look for products that help me economize. & .696 & .023 & .191 \\
\hline C74. I organize every expense that I carry out. & .689 & .186 & .206 \\
\hline C85. When I do my shopping, I spend the right amount. & .647 & .193 & .203 \\
\hline c8o. When choosing what to buy, I make choices taking into consideration my economy. & .643 & .111 & .197 \\
\hline C91. I make my purchases carefully to save money. & .623 & .221 & .243 \\
\hline C88. I avoid buying things that aren't on my shopping list. & .462 & .281 & .177 \\
\hline C89. I avoid buying something so as not to get into debt. & .454 & .144 & .062 \\
\hline C96. I previously list the products that I need before buying them. & .448 & .240 & .248 \\
\hline C64. I think about every purchase that I make. & .134 & .903 & .151 \\
\hline C63. I'm analytical when I make my purchases. & .155 & .770 & .216 \\
\hline C65. I reason with myself before buying something. & .221 & .756 & .228 \\
\hline C66. I decide calmly when buying a product. & .258 & .643 & .061 \\
\hline C62. I consciously decide what to buy when I make a purchase. & .164 & .565 & .042 \\
\hline C67. When I go shopping, I only buy the things that I had willing to buy. & .271 & .553 & .171 \\
\hline C104. I am informed about the products before buying them. & .155 & .134 & .908 \\
\hline C102. I ask about the products before deciding to buy them. & .293 & .127 & .687 \\
\hline C97. I investigate information about the products before buying them. & .327 & .157 & .621 \\
\hline C105. I'm critical when deciding between which products to buy. & .235 & .263 & .593 \\
\hline
\end{tabular}


Table 3. Sub-scales, factorial loads, psychometric index of internal consistency, inter-factor correlations and descriptive statistics of PDMI-Reasoned

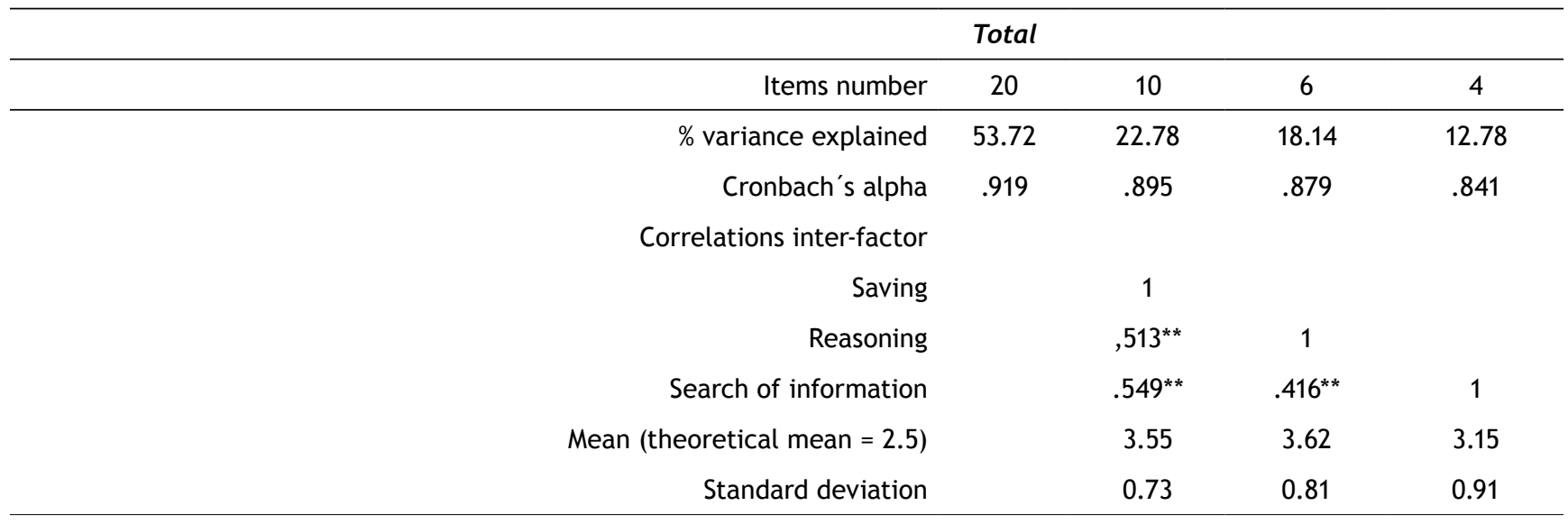

${ }^{* *} p<.001$

Scale of Emotional Decisions in Purchases (PDMI-Emotional)

The appraisal of a five-factor structure of the scale was carried out; for a better fit, the items that increased the error in the other items were eliminated. Modification rates were adjusted with the covariances between the items, in two of the five factors. In this way, a model was obtained as shown in Figure 1.

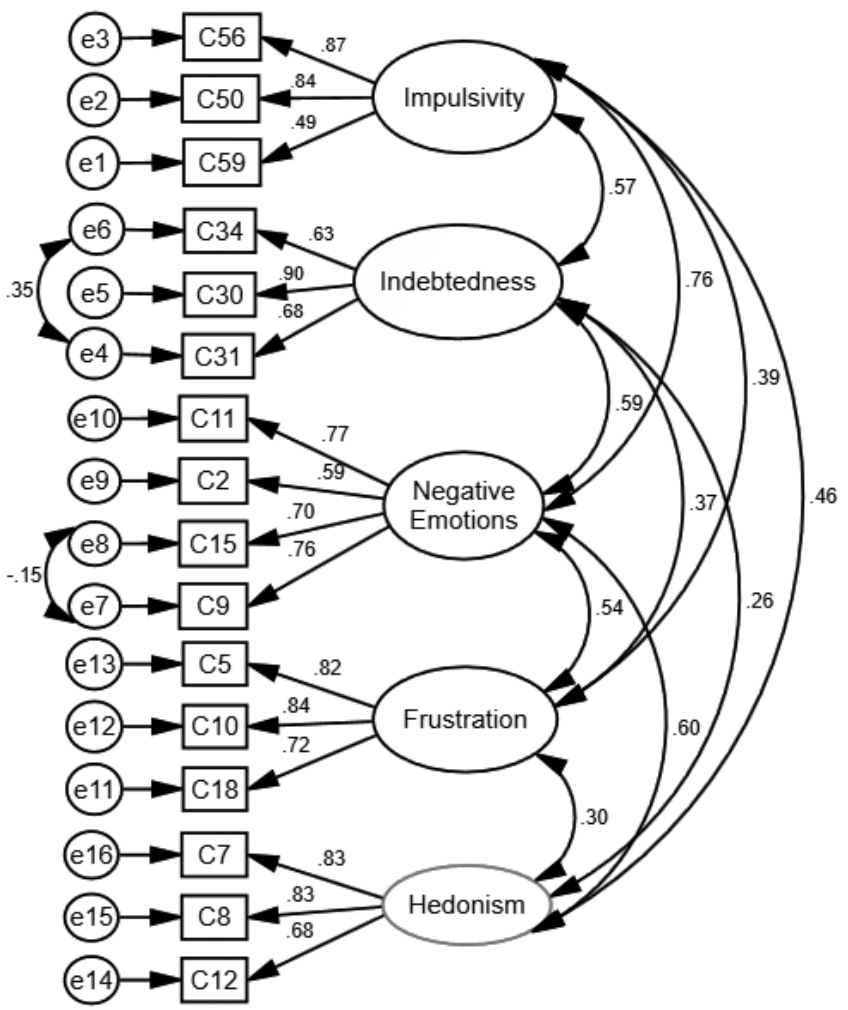

Figure 1. CFA model of PDMI-Emotional.

The model presents a good fit to the data of the theoretical model $\left(\chi^{2}=101.01, g l=92, p=.245 ; C M I N / D F=1.098\right.$, $R M R=.048 ; G F I=.948 ; C F I=.994 ; N F I=.937 ; I F I=.994 ; R M-$ $S E A=.021$, with a minimum range of .000 and a maximum of .043). This confirms the structure of five factors for the emotional decision making of purchases, as identified in the exploratory analysis.

Scale of Reasoned Decisions in Purchases (PDMI-Reasoned).

The evaluation of the three-factor structure of the scale was carried out; for a better fit, the items that increased the error in the other items were eliminated. Modification rates were adjusted with the covariances between the items, in two of the three factors. A model was obtained as shown in Figure 2. Modification rates were adjusted with the covariances between the items, in two of the five factors. In this way, a model was obtained as shown in Figure 1.

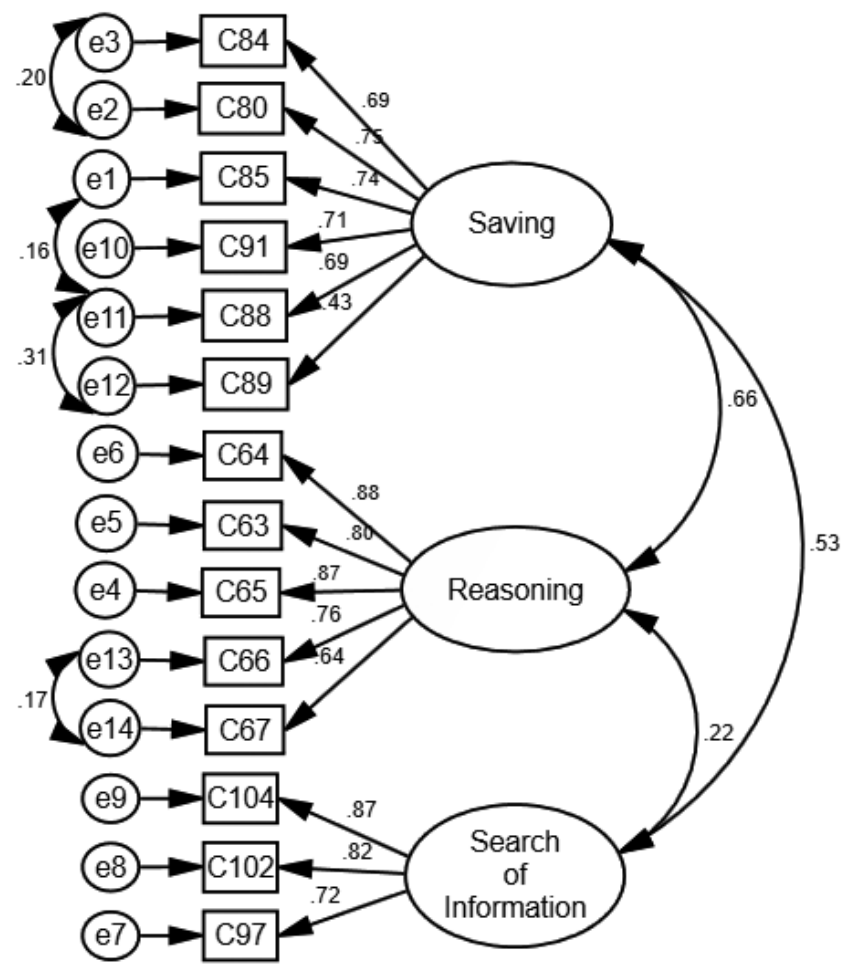

Figure 2. CFA model of PDMI-Reasoned. 
The model presents a good fit to the data of the theoretical model $\left(\chi^{2}=87.20, g l=70, p=.080 ; C M I N / D F=1.246\right.$, $R M R=.039 ; \mathrm{GFI}=.946 ; \mathrm{CFI}=.989 ; \mathrm{NFI}=.947 ; \mathrm{IFI}=.989 ;$ $R M S E A=.034$, with a minimum range of .000 and a maximum of .055). This confirms the structure of three factors for the decision-making of purchases, as identified in the exploratory analysis.

\section{Phase 4. - Convergent, divergent, discriminant and predictive validity.}

To assess convergent and divergent validity, the PDMI-Emotional and PDMI-Reasoned factors were correlated with the factors of the Emotions and affective states of purchases scale (Palacios \& Viloria, 2017) (see Table 4).

Table 4 Correlation indexes between Emotions and affective states of purchases scale, and the PDMI

\begin{tabular}{|c|c|c|}
\hline & \multicolumn{2}{|c|}{$\begin{array}{c}\text { Emotions and affective states } \\
\text { of purchases scale }\end{array}$} \\
\hline & $\begin{array}{l}\text { Positive } \\
\text { emotions }\end{array}$ & $\begin{array}{l}\text { Negative } \\
\text { emotions }\end{array}$ \\
\hline Impulsivity & $.141^{*}$ & $.189^{* *}$ \\
\hline Indebtedness & -.001 & $.196^{* *}$ \\
\hline Negative emotions & .110 & $.223^{* *}$ \\
\hline Frustration & .094 & $.213^{* *}$ \\
\hline Hedonism & $.411^{* *}$ & -.097 \\
\hline Saving & .054 & -.047 \\
\hline Reasoning & $.169^{* *}$ & $-.159 * *$ \\
\hline Search of information & $.142^{*}$ & -.010 \\
\hline
\end{tabular}

Correlations confirm the convergent and divergent validity according to the nomological network of the scale. This is associated with negative emotions with most of the factors of PDMI-Emotional, and positively with the hedonism factor. While for PDMI-Reasoned it doesn't present association of saving factor with any of the emotions and affections dimensions. In regard to reasoning, it is positively associated with positive emotions and negatively with negative emotions, while for the search of information, it only presents association with positive emotions.

Likewise, to ensure divergent validity, the covariance between PDMI-Emotional and PDMI-Reasoned was modelled (See Figure 3).

The model presents a good fit to the data of the theoretical model $\left(\chi^{2}=25.74, g l=18, p=.106 ; C M I N / D F=1.430\right.$, $R M R=.031 ; G F I=.972 ; C F I=.982 ; N F I=.943 ; I F I=.982 ;$ $R M S E A=.045$, with a minimum range of .000 and a maximum of .081). This confirms the structure of two scales of PDMI, also indicating an inversely proportional association between emotional decisions and reasoned decisions, thus ensuring divergent validity.

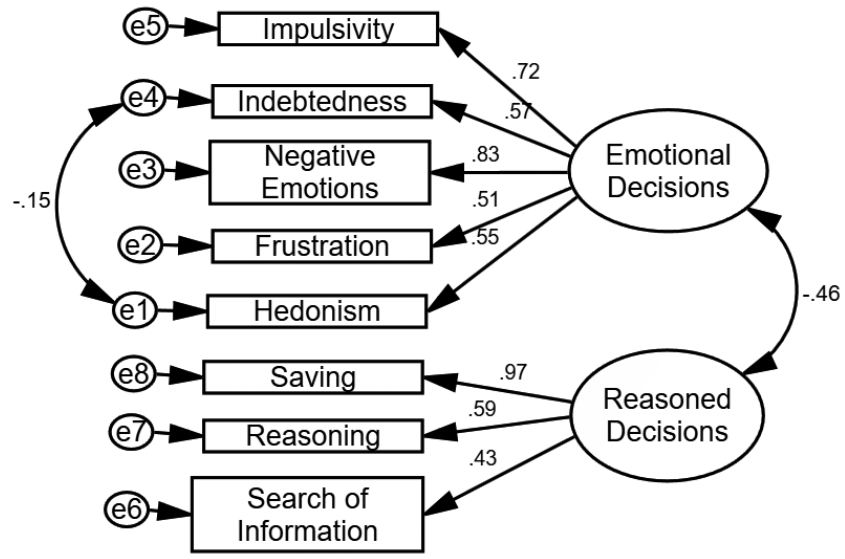

Figure 3. Covariances between PDMI-Emotional

In order to assure the discriminant validity, the Average Variance Extracted (AVE) of the constructs was obtained and compared with squared inter-factor correlations, which AVE requires to be larger than the square correlations inter-factor (Hair, Anderson, Tatham \& Black, 1999). As shown in Tables 5 and 6, each factor the value of AVE is larger than the squares of the correlations, thus ensuring the discriminant validity.

To ensure the predictive validity, the effect of emotional and reasoned decisions on spending per week are processed and analysed with the structural model (See Figure 4). This is according to the relation between emotions and monetary expenditure identified by some authors (Cryder et al., 2008; Garg et al., 2018; Lerner et al. 2004).

The model presents a good fit to the data of the theoretical model $\left(\chi^{2}=42.84, g l=24, p=.010 ; C M I N / D F=\right.$ 1.785, $R M R=27.65 ; \mathrm{GFI}=.959 ; \mathrm{CFI}=.957 ; \mathrm{NFI}=.910 ; \mathrm{IFI}=$ $.958 ;$ RMSEA $=.060$, with a minimum range of .029 and $a$ maximum of .089). In addition, the regression line of emotional decisions is significant at $p=.045$, while the reasoned decisions predictor was not. This confirms the spending per week model, based on the influence of emotional decisions.

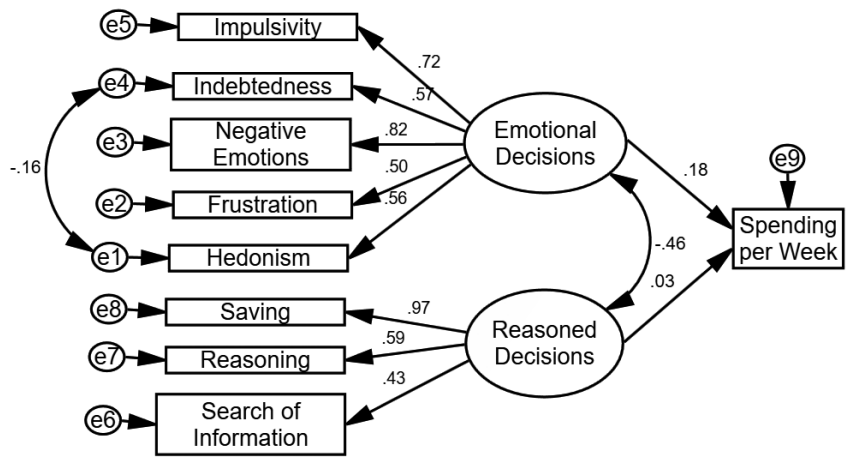

Figure 4. Structural model of spending per week

\section{Discussion}

The goal of the present research was to build develop upon the original ideas of Sproles and Kendall (1986), a way 
Table 5 Squared correlations inter-factor and AVE of the PDMI-Emotional

\begin{tabular}{lccccc}
\hline & Impulsivity & Indebtedness & Negative emotions & Frustration & Hedonism \\
\hline Impulsivity & $(.567)$ & & & & \\
Indebtedness & .208 & $(.556)$ & & & \\
Negative emotions & .334 & .226 & $(.502)$ & $(.632)$ & \\
Frustration & .132 & .112 & .213 & .076 & $(.613)$ \\
Hedonism & .116 & .042 & .230 & & \\
\hline
\end{tabular}

AVE is shown in the diagonal

Table 6 Squared correlations inter-factor and AVE of the PDMI-Reasoned

\begin{tabular}{lccc}
\hline & Saving & Reasoning & Search of Information \\
\hline Saving & $(.458)$ & $(.631)$ & .036 \\
Reasoning & .332 & .192 & $(.649)$ \\
Search of information & .036 \\
\hline
\end{tabular}

AVE is shown in the diagonal

of measuring consumer decision-making styles that would be valid and reliable for assessing these styles in Mexico.

With respect to the variance explained, the PDMI-Emotional presents a conceptually coherent picture with a theoretical meaning. However, the percentage of variance explained per factor is somewhat low, because of the small number of items per factors. However, the factors obtained show theoretical coherence and adjustment in the model. This indicates that a potentially useful, valid and reliable tool has been developed for further work.

With respect to CFA, the size of the sample follows the suggestion of Hoelter (1983) that requires at least $N=200$ for a satisfactory fit; in this study a sample of 218 is considered to be a good fit for the CFA. When it comes to sample size, there is no consensus; some studies identify that the size of the sample must be calculated depending on the study design, the relationships among indicators, and the number of parameters (Brown, 2015). For that reason, it is suggested to replicate these results following this another posture in order to identify a sample size which could strengthen the proposed factorial structure.

The CFA was better adjusted deleting items that generated error to the model, and also drawing covariant paths with the errors. This reveals relational implications (Harrington, 2009). In the first case, in the PDMI-Emotional, a covariation path between items 34 and 31 from the Indebtedness factor that refers to getting into debt when buying something, and on the other hand, borrowing money to buy something. This relation has been shown to be supported by Livingstone and Lunt (1992), identifying that borrowing is associated with debt. In the case of the path between items 15 and 9, it identifies the relation between emotional purchasing and buying due to an outburst; this is in accordance with the evolutionary perspective that emphasises that a flow of emotions were vital for the survival of our ancestors, in turn pushing us to outbursts (Adler, Rosen \& Silverstein, 1998). In the case of the PDMI-Reasoned, a covariation path between items 84 and 80 refers to searching for products which can economize and, choosing the most economic, are related to indicators such as saving money at the time of purchase. In the case of the covariate paths between items 85 and 88 , and 88 and 89 , they are related; on one hand, to spend the right amount, to avoid buying things that are not on the shopping list and, economize; this is related to results which identify that consumers who use a shopping list tend to, on average, spend less than non-list users (Thomas \& Garland, 1993). And on the other hand, using a shopping list helps avoid wasteful expenditures, including get into debt (Thomas \& Garland, 2004).

Development of the inventory from the exploration of the psychological meanings that Mexicans associate with the consumer decision-making styles, provides cultural relevance for the development of psychometric scales (Reyes, 1993). It highlights the way in which the individuals from a certain region share and carry out their economic activities. From this, the composition of inventory by emotional and reasoned scales gives structure for the differentiation of cognitive processing, and affective-emotional style that triggers the purchases of products and services. This coincides with the empirical proposal of Sproles and Kendall (1986), identifying affective and cognitive elements. It also coincides with the theoretical proposal of Kahneman (2011), identifying elements of an intuitive system, which is characterized by being fast and emotional. Elements that can be found embodied in the factorial structure of the PDMI-Emotional, where these dimensions agree with multiple findings on the influence of emotions in economic transactions and consumer decisions (Cui, 2018, Garg et al., 2018; Guven, 2012; lyengar \& Lepper, 2000; Lee \& Yi, 2008; Lerner et al., 2004; Palacios \& Soler, 2017; Palacios \& Viloria, 2017; Schwartz et al., 2002; Soler, Palacios \& Bustos, 2017).

On the other hand, elements of the slow, deliberate and logical system (Kahneman, 2011) are reflected in the PDMI-Reasoned factor structure. Such dimensions coincide with the one presented in different researches (Bloch, Sherrell \& Ridgway, 1986; Kahneman, 2011; Malhotra, 1982; Schmidt \& Spreng, 1996; Scott \& Bruce, 1995; Soler et al., 2017), highlighting the deliberate, slow character that 
involves a certain degree of information processing, as well as contemplating the greatest amount of information so that a decision can be made.

Regarding the descriptive analysis of means, for the dimensions of the PDMI-Emotional, the highest measure is assigned to hedonism, being the only indicator a little above the theoretical average. Next, there is the frustration with various options, and impulsivity follows. The above suggests that, for the selected sample, as far as emotional decisions are concerned, they seem to be motivated initially by hedonic and pleasure states at the time of making the purchases. On the other hand, regarding the dimensions of the PDMI-Reasoned, the highest mean corresponds to reasoning, followed by savings, and finally, the search for information, which suggests that for the selected sample, being calm and analytical when making purchases is what seems to guide the purchases made by the individuals from such a sample. These findings coincide with those identified by Sproles and Kendall (1986), where the highest means correspond to the dimensions of deliberate and reasoned processing of information, in comparison with the emotional or impulsive ones.

Inter-scale correlations and CFA show the moderate association between the PDMI-Emotional dimensions, which supports the idea that scale factors measure different aspects of the same construct. In the same way, it occurs with the dimensions and structure of the PDMI-Reasoned. On the other hand, correlations of the PDMI-Emotional and the PDMI-Reasoned dimensions concerning Emotions and affective states of purchases scale (Palacios \& Viloria, 2017) show consistency in the fact that impulsivity, negative emotions, frustration, anger and indebtedness are associated with negative emotions (lyengar \& Lepper, 2000; Keltner \& Lerner, 2010), while hedonism is associated with positive emotions (Keltner \& Lerner, 2010). Positive relationship of reasoning with positive emotions and inversely proportional relationship with negative emotions has been supported in several studies (Bachkirov, 2015). Previous evidence provides convergent validity, while the appropriate adjustment of the covariance model between the PDMI-Emotional and the PDMI-Reasoned shows evidence of divergent validity, identifying and sustaining the independence of the emotional characteristics of cognitive processing. Having a significantly negative covariance, supporting the need to evaluate differently in the inventory, as well as the decisions aimed at the emotional purchases and the reasoned, coincides with that found by Shiv and Fedorikhin (1999).

The Purchase Decision-Making Inventory (PDMI) turns out to be a useful tool to link and explain behaviors in economic sphere. Evidence of this is the use of the inventory to model monetary expenditure per week. The tested model has adequate adjustment indexes, suggesting, on the one hand, that the scale is useful for predicting economic behaviors, and on the other hand, it highlights the direct influence of the emotional decisions of purchases with the monetary expenditure per week. A finding which is consistent with the evidence of the relationship between emotions decision-making (Loewenstein, 1996), behavior (Lerner \& Keltner, 2000), and monetary spending (Babin \& Darden, 1996; Cryder et al., 2008; Garg et al., 2018; Guven, 2012; Lerner et al., 2004; Rao, Mei \& Zhu, 2016).

The Purchase Decision-Making Inventory (PDMI) has shown to be a useful tool for assessing purchase decisions.
Inventory has adequate factorial weights and it is proposed that for future studies a greater number of items be included for dimensions of the PDMI-Emotional, and also for the searching for information factor of the PDMI-Reasoned. In CFA these factors were left in the limit of the conformation of the factor, and it is not proportional, arising from the rest of the factors of savings and reasoning. It is also proposed that future studies measure a different population from the one used in this study; on the one hand, Mexican populations with different characteristics, and on the other hand, the rest of Latin America. It is the most similar cultural configuration, because as Lysonski et al. (1996) points out, it seems that consumer decision-making and configuration differs significantly in developing countries in contrast to developed countries. These measurements will help to identify the consistency and configuration of the PDMI between cultures, as well as the identification of elements that are shared and those that are idiosyncratic of Mexicans.

\section{Acknowledgements}

This research was funded by the Mexican Consejo Nacional de Ciencia y Tecnología.

\section{References}

Adler, R. S., Rosen, B., \& Silverstein, E. M. (1998). Emotions in negotiation: How to manage fear and anger. Negotiation Journal, 14, 161-179.

Alavi, S. A., Rezaei, S., Valaei, N., \& Wan Ismail, W. K. (2015). Examining shopping mall consumer decision-making styles, satisfaction and purchase intention. The International Review of Retail, Distribution and Consumer Research, 26, 272-303. http:// dx.doi.org/10.1080/09593969.2015.1096808

Arbuckle, J. L. (2016). Amos (Version 24.0) [Software]. Chicago: IBM SPSS.

Babin, B. J., \& Darden, W. R. (1996). Good and bad shopping vibes: Spending and patronage satisfaction. Journal of Business Research, 35, 201-206. http://dx.doi.org/10.1016/01482963(95)00125-5

Bachkirov, A. A. (2015). Managerial decision making under specific emotions. Journal of Managerial Psychology, 30, 861-874. http://dx.doi.org/10.1108/JMP-02-2013-0071

Bloch, P. H., Sherrell, D. L., \& Ridgway, N. M. (1986). Consumer search: An extended framework. Journal of Consumer Research, 13, 119-126. http://dx.doi.org/10.1086/209052

Brown, T. A. (2015). Confirmatory factor analysis for applied research ( $2^{\text {nd }}$ ed.). New York: The Guilford Press.

Chaudhary, S., \& Dey, A. K. (2016). A confirmatory factor analysis of teenage consumer styles inventory: Evidence from India. Amity Business Review, 17, 31-41.

Chuang, S. C., \& Lin, H. M. (2007). The effect of induced positive and negative emotion and openness-to-feeling in student's consumer decision. Journal of Business and Psychology, 22, 65-78. http://dx.doi.org/10.1007/s10869-007-9049-6

CNBC \& SurveyMonkey. (2019). Invest in your spending [Survey]. Retrieved from: https://www.surveymonkey.com/curiosity/cnbc-invest-in-you-july-2019.

Comrey, A., \& Lee, H. (1992). A first course in factor analysis. Hillsdale, NJ: Erlbaum.

Cryder, C. E., Lerner, J. S., Gross, J. J., \& Dahl, R. E. (2008). Misery is not miserly: Sad and self-focused individuals spend more. Psychological Science, 19, 525-530. http://dx.doi.org/10.1111/j.14679280.2008.02118.x 
Cui, Z. (2018). Happiness and consumption: Evidence from China. International Review of Economics, 65, 403-4019. http://dx.doi. org/10.1007/s12232-018-0303-1

Garg, N., Williams, L. A., \& Lerner, J. S. (2018). The misery-is-not-miserly effect revisited: Replication despite opportunities for compensatory consumption. PLOS ONE, 13, e0199433. http:// dx.doi.org/10.1371/journal.pone. 0199433

Guven, C. (2012). Reversing the question: Does happiness affect consumption and savings behavior? Journal of Economic Psychology, 33, 701-717. http://dx.doi.org/10.1016/j.joep.2012.01.002

Hair, J. F., Anderson, R. E., Tatham, R. L., \& Black, W. C. (1999). Análisis de datos multivariante ( $4^{\text {th }}$ ed.). Prentice Hall.

Harrington, D. (2009). Confirmatory factor analysis. New York: Oxford University Press.

Hoelter, J. W. (1983). The analysis of covariance structures: Goodnessof-fit indices. Sociological Methods and Research, 11, 325-344.

IBM Corp. (2017). IBM SPSS Statistics for Macintosh (Version 25.0) [Software]. Armonk, NY: IBM Corp.

lyengar, S. S., \& Lepper, M. (2000). When choice is demotivating: Can one desire too much of a good thing? Journal of Personality and Social Psychology, 79, 995-1006. http://dx.doi.org/10.1037//00223514.79.6.995

Kahneman, D. (2011). Thinking, fast and slow. New York, NY: Farrar, Strauss, Giroux.

Keltner, D., \& Lerner, J. S. (2010). Emotion. In S. T. Fiske, D. T. Gilbert, \& G. Lindzey (Eds.). Handbook of Social Psychology (5th ed.). (pp. 317-352). Hoboken, NJ: Wiley.

Kotler, P., \& Armstrong, G. (1994), Principles of Marketing (6th ed.). Englewood Cliffs, New Jersey: Prentice-Hall.

Lee, G. Y., \& Li, Y. (2008). The effect of shopping emotions and perceived risk on impulsive buying: The moderating role of buying impulsiveness trait. Seoul Journal of Business, 14, 67-92.

Lerner, J. S., \& Keltner, D. (2000). Beyond valence: Toward a model of emotion-specific influences on judgement and choice. Cognition \& Emotion, 14, 473-493. http://dx.doi.org/10.1080/02699930040 2763

Lerner, J. S., Small, D. A., \& Loewenstein, G. (2004). Heart strings and purse strings: Carryover effects of emotions on economic decisions. Psychological Science, 15, 337-341. http://dx.doi. org/10.1111/j.0956-7976.2004.00679.x

Livingstone, S. M., \& Lunt, P. K. (1992). Predicting personal debts and debt repayment: Psychological, social and economic determinants. Journal of Economic Psychology, 13, 111-134. http:// dx.doi.org/10.1016/0167-4870(92)90055-C

Loewenstein, G. (1996). Out of control: Visceral influences on behavior. Organizational Behavior and Human Decision Processes, 65, 272-292. http://dx.doi.org/10.1006/obhd.1996.0028

Lysonski, S., Durvasula, S., \& Zotos, Y. (1996). Consumer decision-making styles: A multi-country investigation. European Journal of Marketing, 30, 10-21. http://dx.doi.org/10.1108/03090 569610153273

Malhotra, N. K. (1982). Information load and consumer decision making. Journal of Consumer Research, 8, 419-430. http:// dx.doi.org/10.1086/208882

Mansilla C., L., Denegri C., M., \& Álvarez E., B. (2016). Relación entre actitudes hacia el endeudamiento y locus de control del consumidor en estudiantes universitarios. Suma Psicológica, 23(1), 1-9. http://dx.doi.org/10.1016/j.sumpsi.2015.11.002

McDonald, W. J. (1993). The roles of demographics, purchase histories, and shopper decision-making styles in predicting consumer catalog loyalty. Journal of Direct Marketing, 7, 55-65. http:// dx.doi.org/10.1002/dir.4000070308

Palacios, J. R., \& Soler, A. L. (2017). Preliminary study of the comparative profile of financial control in university young people. Ciencias Psicológicas, 11, 201- 212. http://dx.doi.org/10.22235/ cp.v11i2.1491
Palacios, J., \& Viloria, E. (2017). Diferencias en las emociones básicas y estados afectivos del consumidor [Differences in the basic emotions and affective states of the consumer]. VIII Congreso Nacional de Investigación UVM. Ciudad de México, del 19 al 21 de octubre.

Rao, Y., Mei, L., \& Zhu, R. (2016). Happiness and stock-market participation: Empirical evidence from China. Journal of Happiness Studies, 17, 271-293. http://dx.doi.org/10.1007/s10902-0149594-4

Reyes L., I. (1993). Las redes semánticas naturales, su conceptualización y su utilización en la construcción de instrumentos. Revista de Psicología Social y Personalidad, 10, 81-97.

Sam, K. M., \& Chatwin, C. (2015). Online consumer decision-making styles for enhanced understanding of Macau online consumer behavior. Asian Pacific Management Review, 20, 100-107. http://dx.doi.org/10.1016/j.apmrv.2014.12.005

Schmidt, J. B., \& Spreng, R. A. (1996). A proposed model of external consumer information search. Journal of the Academy of Marketing Science, 24, 246-256. http://dx.doi.org/10.1177/0092070396243005

Schwartz, B., Ward, A., Monterosso, J., Lyubomirsky, S., White, K., \& Lehman, D. R. (2002). Maximizing versus satisficing: Happiness is a matter of choice. Journal of Personality and Social Psychology, 83, 1178-1197. http://dx.doi.org/10.1037//00223514.83.5.1178

Scott, S. G., \& Bruce, R. A. (1995). Decision-making style: The development and assessment of a new measure. Educational and Psychological Measurement, 5, 818-831. http://dx.doi. org/10.1177/0013164495055005017

Shim, S. (1996). Adolescent consumer decision-making styles: Socialization perspective. Psychology \& Marketing, 13, 547-569.

Shiv, B., \& Fedorikhin, A. (1999). Heart and mind in conflict: The interplay of affect and cognition in consumer decision making. Journal of Consumer Research, 26, 278-292.

Simon-Kucher \& Partners. (2019). The rating economy - Consumer survey. Retrieved from https://www.simon-kucher.com/es/ TheRatingEconomy-BehavioralChanges.

Soler A., F. L., Palacios, J. R., \& Bustos A., J. M. (2017). Significado psicológico del consumo. Revista Electrónica de Psicología de la FES Zaragoza, UNAM, 7, 33-39.

Soler A., F. L., Palacios, J. R., Bustos A., J. M. \& Díaz-Loving, R. (2018). Exploración del significado de la toma de decisiones del consumo: Aproximación desde lo impulsivo y lo razonado. En: Díaz L., R., Reyes, L. I. \& López R., F. (Eds.). Aportaciones Actuales de la Psicología Social. (pp. 897-916), Volumen IV. México: AMEPSO.

Sproles, G. B., \& Kendall, E. L. (1986). A methodology for profiling consumers' decision-making styles. Journal of Consumer Affairs, 20, 267-279.

Thomas, A., \& Garland, R. (1993). Supermarket shopping list: Their effect in consumer expenditure. International Journal of Retail and Distribution Management, 21, 8-14.

Thomas, A., \& Garland, R. (2004). Grocery shopping: List and non-list usage. Marketing Intelligence \& Planning, 22, 623-635. http://dx.doi.org/10.1108/02634500410559015

Vida, I., \& Reardon, J. (2008). Domestic consumption: Rational, affective or normative choice? Journal of Consumer Marketing, 25, 34-44. http://dx.doi.org/10.1108/07363760810845390

Wesley, S., LeHew, M., \& Woodside, A. G. (2006). Consumer decision-making styles and mall shopping behavior: Building theory using exploratory data analysis and the comparative method. Journal of Business Research, 59, 535-548. http://dx.doi. org/10.1016/j.jbusres.2006.01.005 